\title{
Que Mil Flores Desabrochem!
}

John Milton*

É possível delimitar o que é uma adaptação?

Se seguirmos Linda Hutcheon, encontraremos limites muito amplos para designar o que é uma Adaptação: "uma revisitação estendida, deliberada e anunciada a uma obra de arte específica". Isso pode incluir uma ampla gama de obras, incluindo traduções literárias e transcrições de música orquestral para piano a condensações e simplificações de livros, spin-offs, revisões e estudos críticos de obras literárias ou fílmicas. As possibilidades para a adaptação também incluem expansões como prequels e sequels; fanzines e ficção slash; e alusões breves, trechos de música, e exposições de museu (HUTCHEON 2013: 171-2).

Em seus primeiros anos, mais ou menos até 2000, os Estudos da Adaptação estavam muito ligados à adaptação cinematográfica, especialmente de romances; porém, as barreiras caíram. Outras artes como a ópera, o balé, o teatro, as peças de rádio, a pintura, as $\mathrm{HQ}$, e os videogames começaram a ser estudadas, e, com a explosão das mídias os Estudos da Adaptação encampam novas formas como vlogs, mashups, remixes, reboots, amostragens, remodelações e transformações. Essas formas participativas abrem novos horizontes e resultam em "uma mudança de modos de adaptação hermenêutica para performativa", ou melhor, "apropriação" com o artefato literário e cultural sendo transformado de um objeto de contemplação em algo com o que o sujeito pode brincar (VoIGTS-VIRCHOW 2017: 308-318).

Apesar da dificuldade de estabelecer limites e definir o que é e não é adaptação e certa frustração e desnorteamento na parte do pesquisador e estudante, a disciplina dos Estudos em Adaptação está viva e excitante para Thomas Leitch, que enfatiza "um florescimento [efflorescence] igualmente notável de erudição provocativa". Leitch

\footnotetext{
" Universidade de São Paulo

TradTerm, São Paulo, v.38, fevereiro/2021, p. 20-21

Número Especial - III JOTA

www.revistas.usp.br/tradterm
} 
(2012: 103) acredita que a questão dos limites deve ser adiada, como tais limitações prenderia e colocariam restrições em "um campo que pode florescer com mais sucesso quando mil flores desabrocharem".

\section{Referências}

HutCheON, L.; O'FlynN, S. A Theory of Adaptation. London and New York: Routledge. 2013.

LEITCH, T. “Adaptation and Intertextuality, or, What isn'translation an Adaptation, and What Does it Matter?", In: Cartmell, D. (ed.) A Companion to Literature, Film and Adaptation. Oxford: Blackwell.2012, p. 87-104 Z33-269.

VoIGTS, E. "Memes and Recombinant Appropriation: Remix, Mashup, Parody" In: LEITCH, T. (ed.) The Oxford Handbook of Adaptation Studies, New York: Oxford University Press, 2017, p. 308-327. 